\title{
面向生态修复的自然资源资产评估与应用研究
}

以广州市为例

\author{
李晓晖 ${ }^{1,2}$, 萧敬豪 ${ }^{1,2}$, , 王建军 ${ }^{1,2}$, 吴 婕 ${ }^{1,2}$, 龙 闹 ${ }^{1,2}$ \\ 1 广州市城市规划勘测设计研究院,广州 510060 \\ 2 广东省城市感知与监测预警企业重点实验室,广州 510060
}

\begin{abstract}
摘要:生态修复是国土空间治理的重要内容。做好生态受损、功能退化地区的辨识并因地施策,是科学编制国土空间规划、实施 生态修复重大工程的优先任务。基于自然资源资产评估方法,探索提出一种面向生态保护与修复规划的应用路径。在自然资 源资产理念与方法评估辨析基础上,以广州为例,构建在地化的自然资源实物核算、生态系统服务功能价值评估框架,开展生态 修复空间辨识,提出空间规划应对策略。主要研究结论: (1) 2009 年广州市自然资源资产总值约 8334 亿元, 2019 年为 12025 亿 元; (2) 自然资源资产价值总体呈上升趋势; 剔除价格上涨因素后,调节与支持服务价值有所下降,生态保护与修复工作仍待强 化; (3) 提出自然资源资产评估在国土空间规划生态重要性地区识别、生态空间主导功能分区、生态治理重点研判等规划应用。 最后, 就如何提高自然资源资产评估的合理性与准确性,自然资源资产评估方法在不同层次国土空间生态修复规划中的适应 性,如何基于自然资产评估推动生态修复规划实施等方面进行了讨论。
\end{abstract}

关键词 : 自然资源资产评估; 生态修复; 广州市; 国土空间规划

\section{Research on the evaluation and application of natural resources assets for ecological restoration: A case study of Guangzhou City}

\author{
LI Xiaohui ${ }^{1,2}$, XIAO Jinghao ${ }^{1,2, *}$, WANG Jianjun ${ }^{1,2}$, WU Jie ${ }^{1,2}$, LONG Nao $^{1,2}$ \\ 1 Guangzhou Urban Planning \& Design Survey Research Institute, Guangzhou 510060, China \\ 2 The Guangdong Enterprise Key Laboratory for Urban Sensing, Monitoring and Early Warning, Guangzhou 510060, China
}

\begin{abstract}
As a national strategy of land ecological restoration, how to identify priority ecological restoration space and improve regional ecological service function is the current research hotspot and difficulty. This paper, taking Guangzhou as an example, aimed to identify ecological restoration space by evaluating natural resources assets to seek a new tool of territory planning. We found that: (1) the value of natural resources assets in Guangzhou was about 833.4 billion yuan in 2009, compared with 1202.5 billion yuan in 2019; (2) The value of natural assets has increased, but excluding the factors of price rise, the value of regulation and support services has declined; (3) We put forward the application of the evaluation of natural resources assets in space ecological restoration of the territorial spatial planning, including ecological importance area identification, ecological space major function zoning, and key points of ecological governance identification. Finally, this paper discussed how to improve the rationality and accuracy of natural resources assets evaluation, the adaptability of natural resources assets evaluation methods in different scale of land and space ecological restoration planning, and how to promote the implementation of ecological restoration planning based on natural assets
\end{abstract}

基金项目:广东省重点领域研发计划项目(2020B0101130009); 广东省城市感知与监测预警企业重点实验室基金项目(2020B121202019)

收稿日期: 2020-05-14; 网络出版日期:2021-10-09

* 通讯作者 Corresponding author.E-mail: ucsiu@ foxmail.com 
evaluation.

Key Words : evaluation of natural resources assets ; ecological restoration ; Guangzhou ; territory spatial planning

“绿水青山就是金山银山”,党的十八届五中全会提出要坚持保护优先、自然恢复为主,实施山水林田湖 生态保护修复工程。十九届四中全会提出 “健全生态保护和修复制度” 和 “统筹山水林田湖草一体化保护和 修复”。2020 年 9 月, 自然资源部发布《关于开展省级国土空间生态修复规划编制工作的通知》,生态修复迈 人了山水林田湖草整体保护、系统修复、综合治理的阶段。面对快速城市化对人类赖以生存的生态环境造成 的污染和破坏风险 ${ }^{[1]}$, 从区域尺度辨识生态修复空间是国土空间规划开展生态修复的重要前提与研究热 点 ${ }^{[2]}$ 。同时, 相对于生态敏感性分析、生态系统服务功能评价、最小阻力面分析等功能量评估方法, 自然资源 资产评估方法具备对标基准明确、指标口径统一、可比性强等优点, 已成为国内外生态环境保护、生态功能区 划、生态补偿决策的重要依据和基础 ${ }^{[3-6]}$,并已逐渐作为生态规划方法加以应用 ${ }^{[7-8]}$ 。

自然资源资产评估是基于自然资源核算和生态系统服务功能两方面发展起来的。学界对其定义大体可 以归纳为两大类: 一类侧重于自然资源资产的价值体现形式 ${ }^{[9]}$, 认为自然资源资产即资源直接价值与生态系 统服务功能价值之和 ${ }^{[10-13]}$; 另一类则侧重于自然资源资产的实体形式 ${ }^{[14]}$ 。本文认为自然资源资产评估的对 象应包括实物价值以及服务价值两部分, 并分别可以通过自然资源实物价值核算(下文简称为“实物价值核 算”)、生态系统服务功能价值评估(下文简称为“服务价值评估”)两种方法进行测算。

实物价值核算主要是指结合地区资源禀赋,构建在地化的资源核算框架; 从经济价值角度,对其生物、淡 水、碳、土地等实物资产进行货币化计算。例如联合国 SEEA-2012 中心框架提出矿产和能源资源、土地、土 壤资源、木材资源、水生生物资源、其他生物资源、水资源的评估框架。青海省构建的自然生物资源资产、土壤 资源资产、淡水资源资产、碳资源资产、土地资产评估框架 ${ }^{[15]}$ 。

服务价值评估以生态系统服务理论为基础, 对生态系统的供应服务、调节与支持服务、文化服务的功能量 进行评估。Costanza 等 ${ }^{[16]}$ 第一次把全球生态系统的服务功能分为 17 个大类并进行了统计。此后, 我国学者 相继从全国生态系统、某一地区综合系统、单一生态系统等方面对服务价值评估进行了研究 ${ }^{[17-25]}$ 。目前自然 资源资产的服务价值评估可以大致分为两类，即基于单位服务功能价格的方法 (价值功能法) 以及基于单位 面积价值当量因子的方法 (当量因子法)。

以前述为指导, 本文以广州市为例, 建立在地化的自然资源资产评估框架, 从价值总量、价值构成、价值变 化等方面对其 2009 年与 2019 年的自然资源资产进行评估分析, 并提出生态重要性地区识别、生态空间主导 功能分区、生态治理重点研判方法, 以期为国土空间生态修复规划工作引人可量化、可比较、可操作的评估与 应用方法。

\section{1 研究区域}

研究区域为广州市域, 面积约 $7434 \mathrm{~km}^{2}$, 位于粤港澳大湾区中部、南岭山系与珠江河口冲积平原间的过渡 地带。广州市域范围山水林田湖海自然要素丰富齐备, 形成了北部依山、中部沿江、南部滨海的多样化的城市 空间格局与形态。人口和经济集聚规模巨大, 2019 年常住人口已经达 1530.6 万人,地区生产总值 23628.60 亿元。广州市近十年城市高速发展, 建成区快速扩张, 常住人口年均增长 49.7 万人, 建设用地年均增长约 $30 \mathrm{~km}^{2}$,使得广州成为湾区内城市发展与生态环境矛盾最为突出的地区之一 ${ }^{[26]}$ 。

\section{2 数据与方法}

2.1 数据来源

实物价值核算中, 经济动植物数量来源于广州市统计年鉴, 单位价格参考爱采购、新牧网等农贸批发网站 
价格计算;淡水资源数据来源为广州市国民经济和社会发展统计公报,单位价格按照广州市水价计算;碳资源 资产总量参考已有研究 ${ }^{[27]}$, 价格按照煤炭批发价格计算; 土地利用数据参考广州市土地利用变更调查, 价格 按照广州市国有农用地使用权基准地价土地级别价格计算。

服务价值评估中,生态系统分类参考目前我国较为成熟的划分方法 ${ }^{[28]}$, 结合广州生态禀赋特征, 分为农 田、森林、草地、湿地、裸地、水域、公园绿地 7 大类 11 小类生态系统。以土地利用现状数据为基础统计各类生 态系统数据, 同时进一步结合广州市现状公园调查数据识别出建设用地中的公园绿地, 并结合广州市林业调 查数据对土地利用现状数据以及公园绿地中的森林分布情况进行细化, 按照优势林种细分为针叶等 4 类生态 系统类型, 得到 2009 年和 2019 年广州市各类生态系统面积及分布情况 (表 1、图 1)。文化服务价值评估所需 的生态与乡村旅游活动点通过高德地图 POI 进行篮选获得。

表 12009 年、2019 年广州市各类生态系统面积

Table 1 Area of various ecosystems in Guangzhou in 2009 and 2019

\begin{tabular}{|c|c|c|c|}
\hline \multirow{2}{*}{$\begin{array}{l}\text { 生态系统类型 } \\
\text { Type of ecosystem }\end{array}$} & \multicolumn{2}{|c|}{ 面积 Area $/ \mathrm{km}^{2}$} & \multirow{2}{*}{$\begin{array}{c}\text { 变化 } \\
\text { Variation } / \mathrm{km}^{2}\end{array}$} \\
\hline & 2009 年 & 2019 年 & \\
\hline 旱田 Dry farmland & 331.6 & 238.7 & -92.9 \\
\hline 水田 Paddy field & 556.7 & 342.5 & -214.2 \\
\hline 针叶 Coniferous forest & 736.9 & 664.6 & -72.3 \\
\hline 针阔混交 Coniferous and broad-leaved mixed forest & 1732.4 & 1866.5 & 134.0 \\
\hline 阔叶 Broad-leaved forest & 1191.4 & 1102.7 & -88.6 \\
\hline 灌木 Shrub & 63.7 & 175.9 & 112.2 \\
\hline 灌草丛 Brush grass & 46.4 & 74.1 & 27.7 \\
\hline 水域 River & 912.7 & 938.1 & 25.3 \\
\hline 湿地 Wetland & 55.3 & 29.4 & -26.0 \\
\hline 裸地 Barren & 59.0 & 148.8 & 89.8 \\
\hline 公园绿地 Park & 18.6 & 52.1 & 33.5 \\
\hline
\end{tabular}

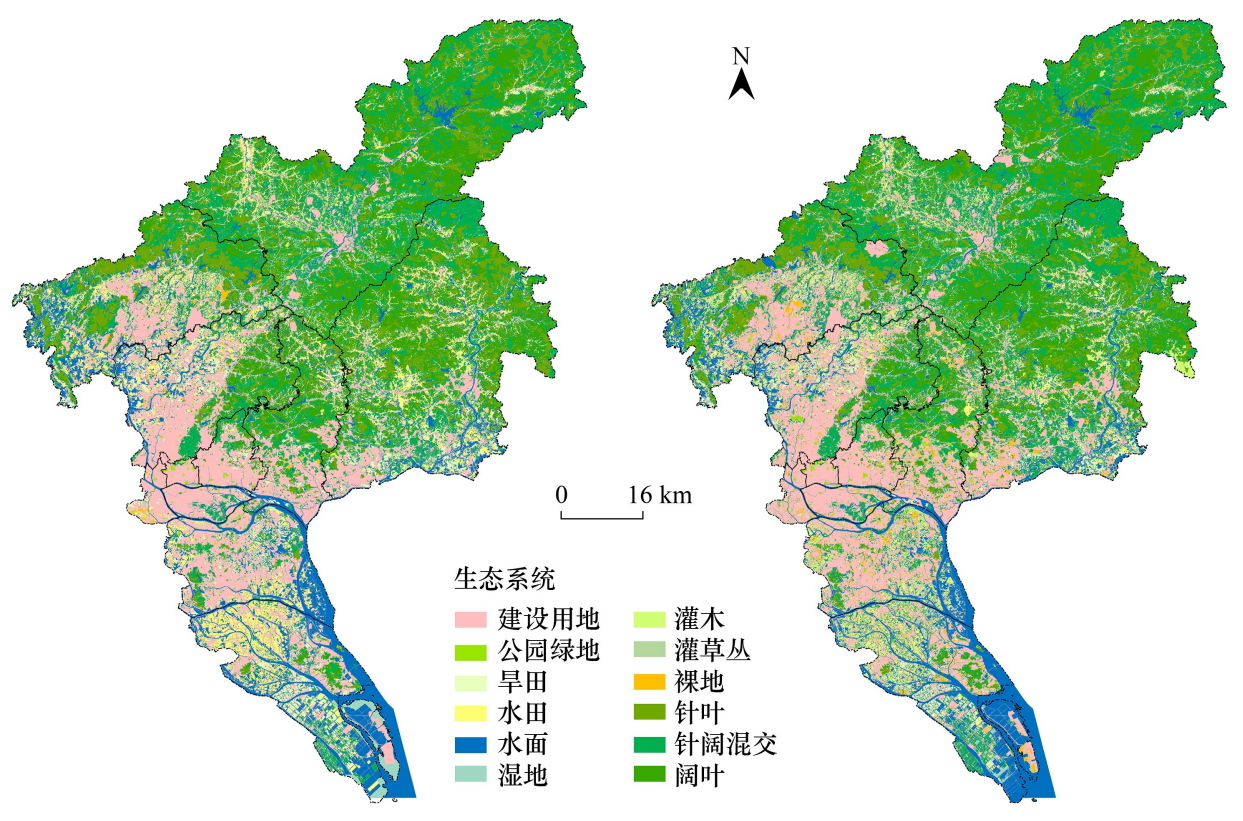

图 12009 年、2019 年广州市生态系统分布图

Fig.1 Distribution map of Guangzhou ecosystem in 2009 and 2019 


\section{2 研究方法}

\subsection{1 研究技术路线}

自然资源资产评估由实物价值核算与服务价值评估两部分组成。本文认为实物价值是对不同自然资源 年末存量的价值量的核算, 是对 “存量”价值的统计;服务价值是基于不同类型生态系统单位面积上各类服务 功能年均价值当量计算 ${ }^{[28]}$, 是对某时间段 (通常为一年) 产生的价值的计算, 为一种 “流量” 价值。由于目前 自然资源资产评估仍未形成统一的评估框架, 实物价值核算与服务价值评估目前存在部分指标内涵重叠的情 况,本文通过调整核算要素在内涵上避免重复,以及通过核减重复价值的方式,对其进行修正: (1)通过统计经 济动植物的年末储量、存栏量的方式, 避免经济动植物的实物价值与食物生产、原料生产等重复。(2)通过在碳 资源资产价值中核减固碳减排价值、在淡水资源中核减水资源供给价值,避免重复计算。

生态修复是生态治理和国土空间规划的重要内容, 关键是要做好生态受损、功能退化地区的辨识并因地 施策。对此, 本文将生态修复作为自然资源资产评估的重要应用场景, 提出基于网格化比对的自然资源服务 价值量时空分析方法, 通过服务价值量的总量对比、价值构成分析、价值演变分析, 形成国土空间生态修复规 划应用路径。具体研究技术路线为:

(1) 结合广州市生态资源禀赋特点,构建实物价值核算、服务价值评估的分析框架; (2) 核算广州市 2009 年、2019 年两个年度自然资源资产价值总量变化,分析资产总值、实物价值、服务价值的构成和变化情况,识 别总体特征。(3) 以服务价值为研究对象, 基于网格化分析( 按照 $1 \mathrm{~km} \times 1 \mathrm{~km}$ 的方格网)对其进行空间汇总统 计; (4) 通过服务价值总量对比、价值构成分析、价值演变分析, 识别生态重要性地区, 提出生态空间主导功能 分区, 研判生态治理重点。

\subsection{2 实物价值核算框架}

结合广州实际,构建经济动植物、淡水资源、碳资源、土地资源 4 大类 15 小类资源实物价值核算框架 (表2)。

表 2 实物价值核算框架

Table 2 Physical value assessment framework

\begin{tabular}{|c|c|c|c|}
\hline \multicolumn{2}{|l|}{ 资源内容 Type of natural resources } & \multicolumn{2}{|c|}{ 价值核算方法 Value counting method } \\
\hline 经济动植物 & 年末活立木储量 & 市场价值法 & $\Gamma^{j}$ \\
\hline Economic animals and plants & 年末经济牲畜存栏量 & & $V_{p}=\sum_{i=1}\left(Q_{P i} \times Q P_{p i}\right)$ \\
\hline 碳资源资 ～～～～～～～资 & 土壤碳 & & 式中, $V_{p}$ 为实物价值量; $Q_{P_{i}}$ 为 $i$ 产品的产量或 \\
\hline Carbon resource assets & 生物碳 & & 数量 $; P_{p i}$ 为 $i$ 产品单价 \\
\hline 淡水资源资产 Freshwater resources assets & 水资源总量 & & \\
\hline 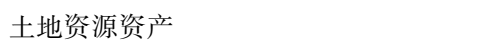 & 耕地 (水田) & & \\
\hline \multirow[t]{8}{*}{ Land resources assets } & 耕地( 旱地) & & \\
\hline & 园地 & & \\
\hline & 林地 & & \\
\hline & 坑塘水面 & & \\
\hline & 设施农用地 & & \\
\hline & 草地 (其他草地) & & \\
\hline & 沿海滩涂 & & \\
\hline & 内陆滩涂 & & \\
\hline
\end{tabular}

\subsection{3 服务价值评估框架}

首先, 基于生态系统服务价值当量因子法 ${ }^{[28]}$, 建立供应服务价值、支持服务与调节服务价值、文化服务价 值 3 大类 11 项服务价值指标。当量因子价值结合历年 CPI 进行修正。以 2015 年 3406.5 元 $/ \mathrm{hm}^{2}$ 为基数， 2019 年当量为 3530 元 $/ \mathrm{hm}^{2} ; 2009$ 年为 2873 元 $/ \mathrm{hm}^{2}$ 。

其次, 生态系统服务功能呈现出与生态结构和生态功能密切相关的时空动态变化过程 ${ }^{[28]}$, 当量因子法作 
为静态评估方法需结合当地生态禀赋特征进行在地化修正。为此,本文基于功能价值法提出初级净生产力调 节系数、食物生产调节系数、水资源供给调节系数,对部分服务价值进行在地化修正; 结合粤港澳大湾区生态 与乡村旅游、碳交易发展情况,对文化服务价值、固碳减排价值进行修正 (表 3、表 4), 以提升当量因子法在岭 南地区的适用性。

表 32009 年广州市自然资源资产服务价值当量表 $/\left(\right.$ 万元 $\left./ \mathrm{hm}^{2}\right)$

Table 3 Table of service value equivalent of natural assets in Guangzhou in 2009

\begin{tabular}{|c|c|c|c|c|c|c|c|c|c|c|}
\hline \multirow{2}{*}{$\begin{array}{l}\text { 生态系统 } \\
\text { Ecosystem }\end{array}$} & \multicolumn{3}{|c|}{$\begin{array}{c}\text { 供给服务 } \\
\text { Provisioning services }\end{array}$} & \multicolumn{7}{|c|}{$\begin{array}{c}\text { 调节与支持服务 } \\
\text { Regulating and supporting services }\end{array}$} \\
\hline & $\begin{array}{l}\text { 食物 } \\
\text { 生产 }\end{array}$ & $\begin{array}{l}\text { 原料 } \\
\text { 生产 }\end{array}$ & $\begin{array}{c}\text { 水资源 } \\
\text { 供给 }\end{array}$ & $\begin{array}{l}\text { 气体 } \\
\text { 调节 }\end{array}$ & $\begin{array}{l}\text { 气候 } \\
\text { 调节 }\end{array}$ & $\begin{array}{l}\text { 净化 } \\
\text { 环境 }\end{array}$ & $\begin{array}{l}\text { 固碳 } \\
\text { 减排 }\end{array}$ & $\begin{array}{l}\text { 土壤 } \\
\text { 保持 }\end{array}$ & $\begin{array}{l}\text { 养分 } \\
\text { 循环 }\end{array}$ & $\begin{array}{l}\text { 生物 } \\
\text { 多样性 }\end{array}$ \\
\hline 旱田 Dry farmland & 1.96 & 0.16 & 0.00 & 0.26 & 0.14 & 0.04 & 0.00 & 0.30 & 0.05 & 0.05 \\
\hline 水田 Paddy field & 3.14 & 0.04 & -0.90 & 0.43 & 0.22 & 0.07 & 0.00 & 0.00 & 0.07 & 0.08 \\
\hline 针叶 Coniferous forest & 0.51 & 0.20 & 0.91 & 0.69 & 2.05 & 0.60 & 0.04 & 0.59 & 0.06 & 0.76 \\
\hline $\begin{array}{l}\text { 针阔混交 } \\
\text { Coniferous and broad-leaved mixed forest }\end{array}$ & 0.72 & 0.28 & 1.38 & 0.44 & 1.16 & 3.47 & 0.04 & 0.82 & 1.41 & 0.11 \\
\hline 阔叶 Broad-leaved forest & 0.67 & 0.26 & 1.38 & 0.34 & 0.84 & 2.52 & 0.04 & 0.76 & 1.03 & 0.08 \\
\hline 灌木 Shrub & 0.44 & 0.17 & 0.91 & 0.53 & 1.59 & 0.48 & 0.00 & 0.49 & 0.05 & 0.59 \\
\hline 灌草丛 Brush grass & 0.88 & 0.22 & 0.91 & 0.86 & 2.28 & 0.75 & 0.00 & 0.69 & 0.08 & 0.95 \\
\hline 湿地 Wetland & 1.18 & 0.20 & 8.72 & 0.55 & 1.03 & 1.03 & 0.00 & 0.66 & 0.05 & 2.26 \\
\hline 裸地 Barren & 0.00 & 0.00 & 0.00 & 0.01 & 0.00 & 0.03 & 0.00 & 0.01 & 0.00 & 0.01 \\
\hline 水系 River & 1.85 & 0.09 & 28.00 & 0.22 & 0.66 & 1.59 & 0.00 & 0.27 & 0.02 & 0.73 \\
\hline 公园绿地 Park & 0.89 & 0.19 & 1.38 & 0.27 & 0.65 & 0.25 & 0.00 & 0.31 & 0.10 & 0.29 \\
\hline
\end{tabular}

表 42019 年广州市自然资源资产服务价值当量表 $/\left(\right.$ 万元 $\left./ \mathrm{hm}^{2}\right)$

Table 4 Table of service value equivalent of natural assets in Guangzhou in 2019

\begin{tabular}{|c|c|c|c|c|c|c|c|c|c|c|}
\hline \multirow{2}{*}{$\begin{array}{l}\text { 生态系统 } \\
\text { Ecosystem }\end{array}$} & \multicolumn{3}{|c|}{$\begin{array}{c}\text { 供给服务 } \\
\text { Provisioning services }\end{array}$} & \multicolumn{7}{|c|}{$\begin{array}{c}\text { 调节与支持服务 } \\
\text { Regulating and supporting services }\end{array}$} \\
\hline & $\begin{array}{l}\text { 食物 } \\
\text { 生产 }\end{array}$ & $\begin{array}{l}\text { 原料 } \\
\text { 生产 }\end{array}$ & $\begin{array}{c}\text { 水资源 } \\
\text { 供给 }\end{array}$ & $\begin{array}{l}\text { 气体 } \\
\text { 调节 }\end{array}$ & $\begin{array}{l}\text { 气候 } \\
\text { 调节 }\end{array}$ & $\begin{array}{l}\text { 净化 } \\
\text { 环境 }\end{array}$ & $\begin{array}{l}\text { 固碳 } \\
\text { 减排 }\end{array}$ & $\begin{array}{l}\text { 土壤 } \\
\text { 保持 }\end{array}$ & $\begin{array}{l}\text { 养分 } \\
\text { 循环 }\end{array}$ & $\begin{array}{l}\text { 生物 } \\
\text { 多样性 }\end{array}$ \\
\hline 旱田 Dry farmland & 3.41 & 0.19 & 0.00 & 0.32 & 0.17 & 0.05 & 0.00 & 0.36 & 0.06 & 0.06 \\
\hline 水田 Paddy field & 5.45 & 0.04 & -0.62 & 0.53 & 0.27 & 0.08 & 0.00 & 0.00 & 0.09 & 0.10 \\
\hline 针叶 Coniferous forest & 0.88 & 0.26 & 1.22 & 0.85 & 2.52 & 0.74 & 0.04 & 0.73 & 0.08 & 0.94 \\
\hline $\begin{array}{l}\text { 针阔混交 } \\
\text { Coniferous and broad-leaved mixed forest }\end{array}$ & 1.24 & 0.19 & 1.84 & 0.53 & 1.43 & 4.27 & 0.04 & 1.01 & 1.74 & 0.13 \\
\hline 阔叶 Broad-leaved forest & 1.16 & 0.14 & 1.84 & 0.42 & 1.03 & 3.10 & 0.04 & 0.94 & 1.26 & 0.10 \\
\hline 灌木 Shrub & 0.76 & 0.20 & 1.22 & 0.65 & 1.96 & 0.59 & 0.00 & 0.61 & 0.06 & 0.73 \\
\hline 灌草丛 Brush grass & 1.52 & 0.30 & 1.22 & 1.06 & 2.80 & 0.92 & 0.00 & 0.85 & 0.10 & 1.17 \\
\hline 湿地 Wetland & 2.05 & 0.18 & 11.63 & 0.67 & 1.27 & 1.27 & 0.00 & 0.82 & 0.06 & 2.78 \\
\hline 裸地 Barren & 0.00 & 0.00 & 0.00 & 0.01 & 0.00 & 0.04 & 0.00 & 0.01 & 0.00 & 0.01 \\
\hline 水系 River & 0.28 & 0.08 & 37.36 & 0.27 & 0.81 & 1.96 & 0.00 & 0.33 & 0.02 & 0.90 \\
\hline 公园绿地 Park & 1.55 & 0.18 & 1.84 & 0.34 & 0.79 & 0.31 & 0.00 & 0.39 & 0.13 & 0.36 \\
\hline
\end{tabular}

(1) 在地化调节系数计算方法

农田、针叶林、针阔混交林、阔叶林、灌木、灌草丛 6 类生态系统的服务价值按照初级净生产力调节系数进 行调整。该系数为广州市 ${ }^{[29]}$ 与全国 ${ }^{[30]}$ 的初级净生产力之比,依次为 $1.36 、 1.41 、 1.72 、 1.35 、 1.31 、 1.52$ 。食物 生产调节系数按照当年粮食、牲畜、三乌、水产品总价格与基于当量因子法计算的食物生产价值之比计算, 2009 年调节系数为 $8.04,2019$ 年为 11.3 。水资源供给调节系数按照当年年供水价值与当量因子法计算的水 资源供给价值之比计算, 2009 年调节系数为 $5.44,2019$ 年为 5.91 。 
(2) 文化服务价值评估方法

文化服务价值是地区经济综合发展水平与自然资源游憩服务水平的综合反映。文化服务价值的实现形 式十分多样,包括在自然乡野和城市中的各种游憩、休闲、教育等活动,难以对其价值进行全面准确地量化。 考虑到自然资源的主体是分布于城市建成区外的生态、农业地区, 其文化服务实现形式主要是生态、乡村旅游 活动。为此, 本文以生态、乡村旅游总收人为基础对文化服务价值进行评估计算。按照 2019 年乡村旅游占全 省旅游总收人 $30.3 \%$ 推算, 2009 年文化服务价值 292 亿元、2019 年 1208 亿元。在此基础上按照广州市生态 与乡村旅游活动点缓冲距离进行空间递减价值分配。

\section{3 结果与分析}

3.1 自然资源资产价值总量与结构特征

2009 年广州市自然资源资产总值约 8334 亿元, 2019 年为 12025 亿元, 近十年间年均增长率 3.7\% (表 5)。 虽然自然资源资产总值持续增长, 但由于其年均增长率低于国内生产总值增长率, 导致广州市自然资源资产 总值与国内生产总值之比从 2009 年的 $91.0 \%$ 下降至 2019 年的 $50.9 \%$ 。

表 52009 年、2019广州市自然资源资产价值构成/亿元

Table 5 Value composition of natural assets in Guangzhou in 2009 and 2019

\begin{tabular}{|c|c|c|c|c|c|c|c|}
\hline & \multirow{2}{*}{$\begin{array}{c}\text { 价值构成 } \\
\text { Value composition }\end{array}$} & \multicolumn{2}{|c|}{$\begin{array}{l}\text { 总值/亿元 } \\
\text { Gross value }\end{array}$} & \multicolumn{2}{|c|}{$\begin{array}{c}\text { 占大类比例 } / \% \\
\text { Proportion in } \\
\text { major categories }\end{array}$} & \multirow{2}{*}{$\begin{array}{c}\text { 年均增幅/\% } \\
\text { Average annual } \\
\text { growth rate }\end{array}$} & \multirow{2}{*}{$\begin{array}{c}\text { 剔除价格上涨因素后 } \\
\text { 的年均增幅/\% } \\
\text { Average annual growth rate } \\
\text { after excluding price } \\
\text { rise factors }\end{array}$} \\
\hline & & 2009 年 & 2019 年 & 2009 年 & 2019 年 & & \\
\hline 实物价值 & 经济动植物资产 & 223.8 & 329.4 & 3.0 & 3.0 & 3.90 & 1.90 \\
\hline \multirow[t]{4}{*}{ Resource value } & 淡水资源资产 & 90.2 & 60.5 & 1.2 & 1.2 & -3.92 & -6.02 \\
\hline & 碳资源资产 & 4435.5 & 6014.8 & 60.1 & 60.1 & 3.10 & 1.00 \\
\hline & 土地资产 & 2627.9 & 3566.1 & 35.6 & 35.6 & 3.10 & 1.00 \\
\hline & 总计 & 7377.4 & 9970.8 & 100.0 & 100.0 & 3.10 & 1.00 \\
\hline 服务价值 & 供应服务价值 & 383 & 502.1 & 40.0 & 40.0 & 2.80 & 0.70 \\
\hline \multirow[t]{13}{*}{ Service value } & 食物生产 & 68 & 74.9 & 7.1 & 7.1 & 1.00 & -1.10 \\
\hline & 原料生产 & 11.3 & 8.7 & 1.2 & 1.2 & -2.60 & -4.60 \\
\hline & 水资源供给 & 303.6 & 418.5 & 31.7 & 31.7 & 3.30 & 1.20 \\
\hline & 调节与支持服务价值 & 282.3 & 344.2 & 29.5 & 29.5 & 2.00 & -0.10 \\
\hline & 气体调节 & 23.3 & 27.4 & 2.4 & 2.4 & 1.60 & -0.40 \\
\hline & 气候调节 & 56.3 & 69.1 & 5.9 & 5.9 & 2.10 & 0.00 \\
\hline & 净化环境 & 112.3 & 137.9 & 11.7 & 11.7 & 2.10 & 0.00 \\
\hline & 固碳减排 & 1.5 & 1.4 & 0.2 & 0.2 & -0.10 & -2.20 \\
\hline & 土壤保持 & 32.4 & 39.7 & 3.4 & 3.4 & 2.10 & 0.00 \\
\hline & 养分循环 & 38.1 & 47.7 & 4.0 & 4.0 & 2.30 & 0.20 \\
\hline & 生物多样性 & 18.5 & 21 & 1.9 & 1.9 & 1.30 & -0.80 \\
\hline & 文化服务价值 & 292.1 & 1207.7 & $30.5 \%$ & 30.5 & 15.30 & 13.20 \\
\hline & 总计 & 957.4 & 2054 & 100.0 & 100.0 & 7.90 & 5.80 \\
\hline
\end{tabular}

其中, 实物价值构成变化较小。实物价值大类占比依次为碳资源资产 $>$ 土地资源资产 $>$ 经济动植物资产 $>$ 淡水资源资产。服务价值构成变化较大。服务价值大类占比由 2009 年的供应服务价值>文化服务价值>调 节与支持服务价值, 转变为 2019 年的文化服务价值>供应服务价值>调节与支持服务价值。从服务价值的小 类构成来看, 原料生产、固碳减排年均增长率已经呈现负增长趋势。若进一步剔除价格上涨因素, 除文化服务 $(13.2 \%)$ 、水资源供给 $(1.2 \%)$ 、养分循环 $(0.2 \%)$ 呈正增长以外,其余原料生产 $(-4.6 \%)$ 、固碳减排 $(-2.2 \%)$ 、 食物生产 $(-1.1 \%)$ 、生物多样性 $(-0.8 \%)$ 等服务价值均呈现负增长。 
从分析结果来看, 虽然近十年广州市自然资源资产总值有所上升,但剔除价格上涨因素后,调节与支持服 务价值总体降低了 $0.1 \%$; 供应服务价值中食物生产、原料生产价值均呈下跌趋势, 反映出生态系统功能的局 部弱化或未有同步提升,需要进一步通过资源保护利用优化与生态修复,实现自然资源资产的保值增值。为 此, 结合自然资源保护修复的需要, 重点基于服务价值的量化与空间化提出生态空间保护与修复规划路径, 支 撑国土空间规划工作的开展。

\section{2 基于服务价值量的生态重要性地区识别与分级保护}

自然资源服务高价值区作为生态重要性地区, 是科学构建国土空间生态格局的重要依据。参考自然断点 法对网格价值的分段结果, 将网格价值排序前 $20 \%$ 的识别为生态高价值空间,作为国土空间中划分生态空间 的重要依据; 排序 20\%-40\%的网格,作为农业空间、城镇开发边界中的特别用途区划分的重要依据。在国 土空间规划中,具体结合地物、用地以及自然保护地范围边界开展生态空间格局构建以及生态保护红线、自然 保护地等的划定工作。

分析结果显示,广州供应服务高价值地区主要分布在市域北部山林集中分布地区,增江下游、白云区东北 部、番禺东南部、南沙西南部、花都西部等农业集中地区(图 2)。调节与支持服务高价值地区主要分布在广州 北部山林地区 (图 3)。文化服务高价值地区基本覆盖供应服务、调节与支持服务高价值地区, 反映出文化服 务在生态服务系统中的从属性(图 4)。

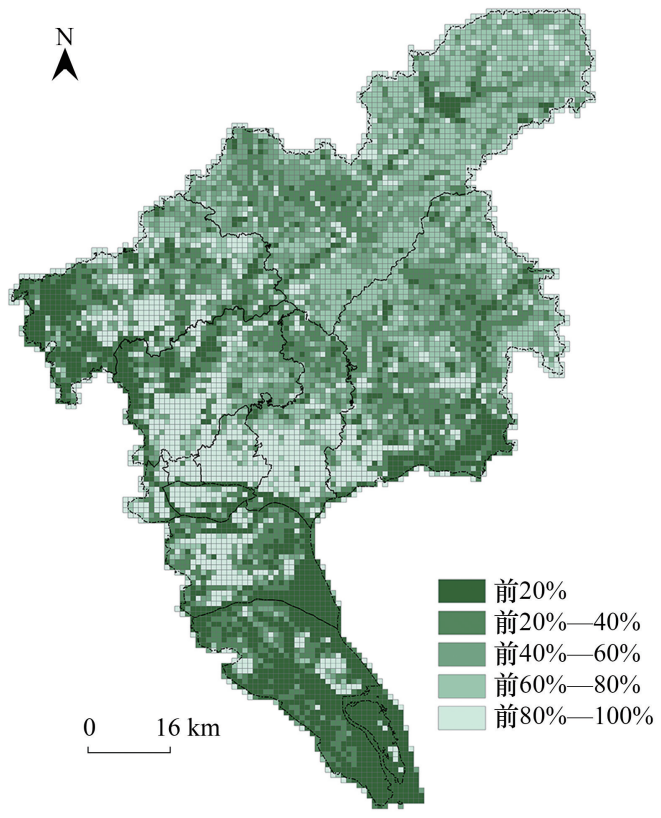

图 22019 年供应服务价值分布

Fig.2 Value distribution of supply services in 2019

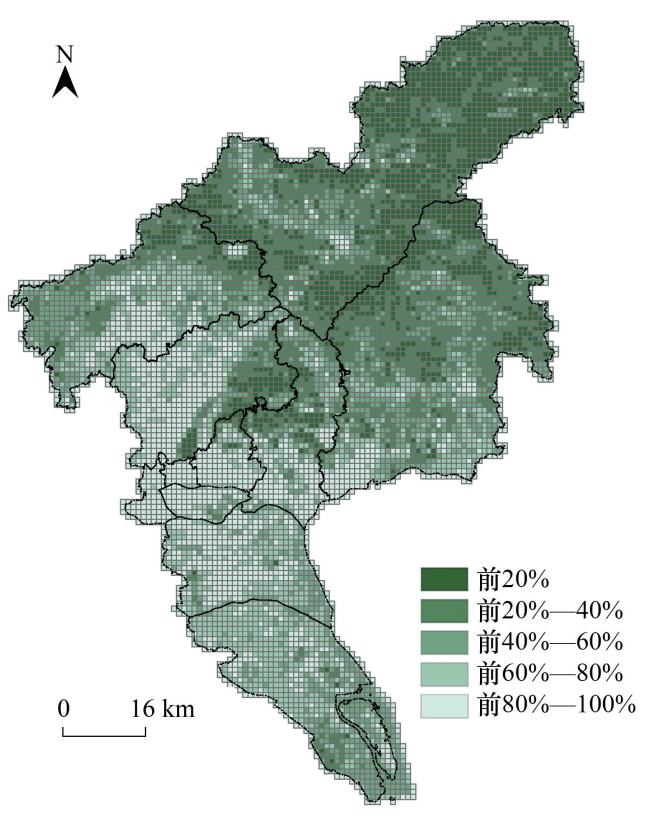

图 32019 年调节与支持服务价值分布

Fig.3 Value distribution of regulatory and support services in 2019

3.3 基于服务价值构成的生态空间主导功能分区

分类保护策略有利于提出更具针对性的规划环境目标 ${ }^{[31-32]}$ 。基于不同地区服务价值的构成情况,识别 地区主导服务价值, 为明确生态空间功能定位以及差异化地进行保护利用、改善提升提供指导。考虑到调节 与支持服务价值在维护整体生态系统服务功能的基础性与支撑性，同一网格按照调节与支持服务>供应服 务>文化服务的优先级进行判定, 确定网格的主导服务功能,提出分区引导策略(图 5)。

分析结果显示, 调节与支持服务作为主导服务功能的网格, 占全市网格 $20.1 \%$, 主要是分布于广州中部、 北部的山地森林生态系统, 发挥着重要的净化环境、气候调节、固碳减排等功能, 是广州最重要的生态源地和 生态屏障区。该类地区应结合生态保护红线划定、自然保护地优化调整等工作,固化生态空间保护,严格实施 
开发建设管控。

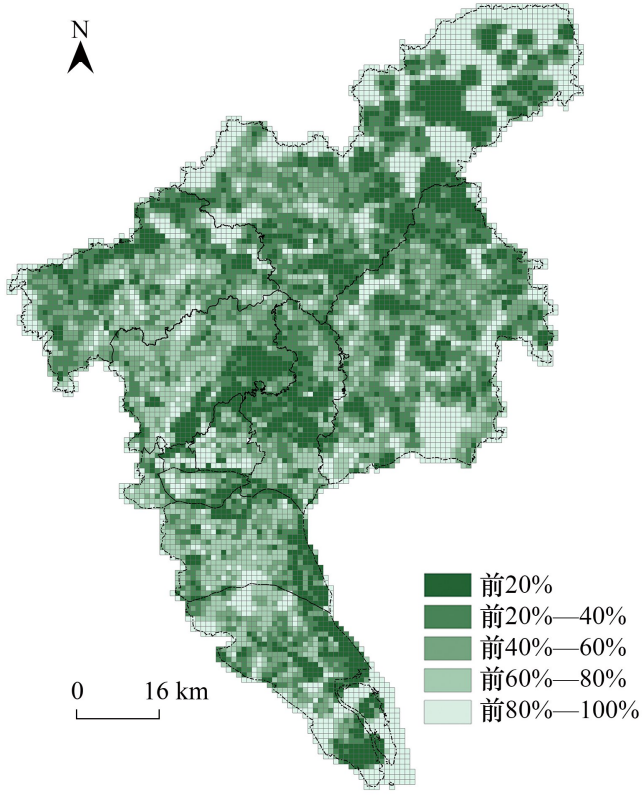

图 42019 年文化服务价值分布

Fig.4 Value distribution of cultural services in 2019

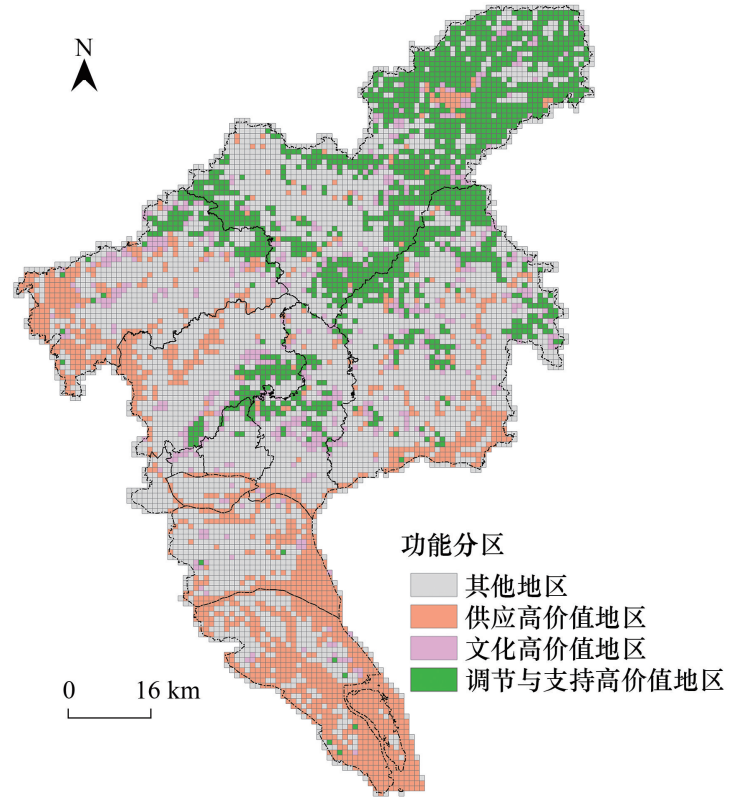

图 5 主导功能分类

Fig.5 Classification of spatial dominant functions

供应服务作为主导功能的网格,占全市网格的 $19.6 \%$,主要分布于广州珠江、流溪河、增江等主要河流沿 线,南部河网区及西北部山前平原,是水系、耕地、林园地集中的农业生产集中区。该类地区对应的服务功能 主要就是水资源供给与食物生产,应从水安全出发重点协调流域保护与城镇布局的关系,在划定城镇开发边 界中合理协调此类地区的避让保留; 针对农业空间和耕地保护,结合此类地区规划永久基本农田集中区、储备 区,推进高标准农田建设、土地综合整治等工作。

文化服务作为主导功能的网格,占全市网格的 $6.8 \%$,与广州森林公园、风景名胜区、远郊村落以及历史文 化名镇、名村的分布关联性较强。该类地区是发展生态旅游、乡村旅游的重要载体, 可通过建设美丽乡村、实 施乡村振兴, 延伸以绿道为代表的城乡休闲游憩网络, 实现生态价值的多元化转化, 同时也需防止为提升文化 服务功能过度 “透支”其他服务功能, 导致整体服务价值下降。

3.4 基于服务价值演变的生态治理重点研判与生态修复

围绕生态治理与生态修复, 从生态系统服务功能演变出发, 通过对服务价值时空变化研判, 明确生态治理 与生态修复的目标与重点。对网格化的不同时期服务价值量变化情况进行分析, 识别服务价值快速下降地区 (已剔除 CPI 影响) (表 6)。分析结果显示, 供应服务主要受耕地减少影响, 其价值下降网格占全部分析网格 的3\% (图6); 调节与支持服务受林地、湿地减少影响，价值实际下降的网格为11\%(图7)。两者空间布局与

表 6 基于网格的服务价值增长情况占比

Table 6 Proportion of service value growth based on Grid

\begin{tabular}{lccc}
\hline $\begin{array}{l}\text { 服务大类 } \\
\text { Service category }\end{array}$ & $\begin{array}{c}\text { 下降 } / \% \\
\text { Decline }\end{array}$ & $\begin{array}{c}\text { 低于价格上涨 } \% \\
\text { Below price rise }\end{array}$ & $\begin{array}{c}\text { 高于价格上涨/\% } \\
\text { Higher than price rise }\end{array}$ \\
\hline 供应服务价值文化服务 Provisioning services & 3.08 & 0.09 & 96.83 \\
调节与支持服务价值 Regulating and supporting services & 10.52 & 0.90 & 88.58 \\
文化服务价值 Cultural services & 0.70 & 15.00 & 84.30 \\
\hline
\end{tabular}


城镇重点发展区相匹配, 主要与受城镇开发建设活动影响较大有关。文化服务价值下降网格为 $16 \%$,多位于 与城镇建成区相距较远的郊野地区(图 8)。

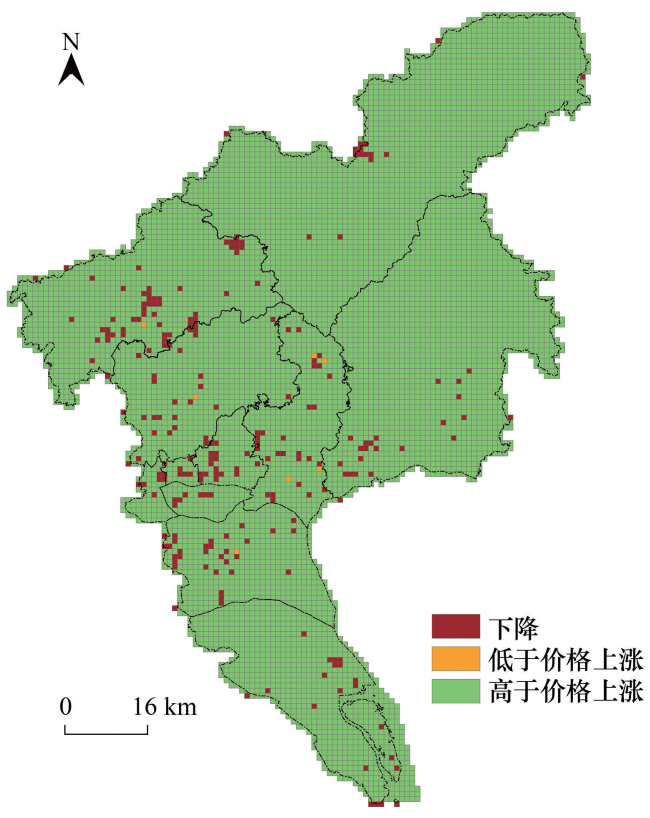

图 6 供应服务价值变化

Fig.6 Change in value of supply services

在此基础上,基于服务价值总量与变化进行矩阵判 断, 明确生态治理的重点方向, 尤其关注生态受损地区 的生态修复行动 (图 9)。(1) 服务价值高且呈增值趋 势的区域可界定为生态优质区,重点是强化生态保护与 维育, 以生物多样性保护提升为关键, 进一步提升生态 系统质量和稳定性。(2) 服务价值低但呈增值趋势的 区域可界定为生态改善区,重点是生态品质提升与价值 转化,可通过农业公园、郊野公园、绿道碧道等游彭空间 体系建设推动生态环境改善与复合利用。(3)服务价 值低且呈减值趋势的区域可界定为生态退化 (转化) 区,通常为已发生用途转化的城乡开发建设地区,一方 面是合理评估和保障生态安全,避免地质、洪涝、水土流 失等风险,一方面还需保留保护必要的蓝绿空间、公园 绿地, 形成与生产、生活相融合的生态空间。(4)服务 价值高且呈减值趋势的区域可界定为生态受损区, 是生 态治理的重中之重,应基于生态系统类型、生态受损程 度,相应制定生态修复导向和重点措施,指导专项规划、 详细规划以及生态修复工程的具体设计实施。如对山

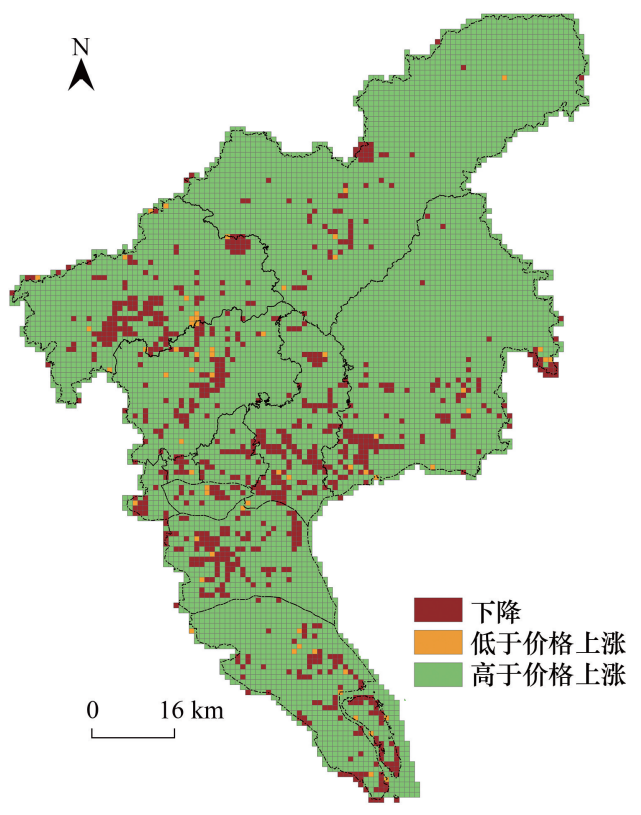

图 7 调节与支持服务价值变化

Fig.7 Change in value of regulatory and support services

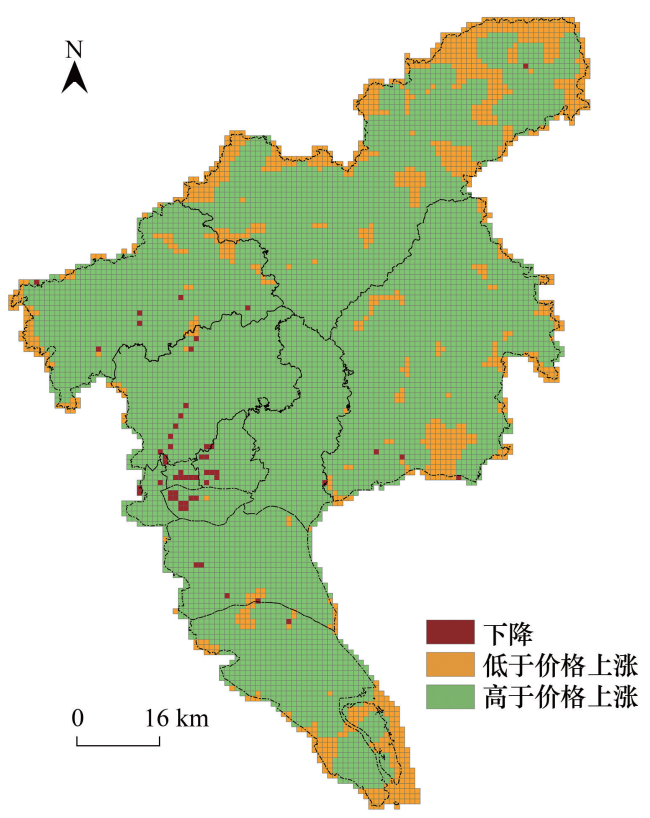

图 8 文化服务价值变化

Fig.8 Change in value of cultural services 地型生态受损区, 需具体开展因开山采石、违法建设导致的受损山体修复,防治崩塌、滑坡等地质灾害,充分利 用岭南地带性乡土植被开展山体复绿, 加强山体周边违法建设管控, 实施拆违建绿; 乡村型生态受损区可结合 土地综合整治,推动乡村建设用地复层复耕,田、水、路、林、村综合整治,保护维育乡村生态空间;海域受损区 
可开展岸线和海岛修复治理,推进生态功能退化岸段整 治修复, 实施红树林栽植工程和生物多样性提升工 程等。

\section{4 讨论与结论}

4.1 讨论

4.1.1 提高自然资源资产评估的合理性与准确性

自然资源资产评估体系仍在探索完善阶段,还未有 统一、标准的方法体系, 评估方法、价值化参数、评估结 果存在主观与客观上的差异, 令自然资源资产价值合理 性与准确性呈现较多局限。如实物价值虽然有相对成 熟的评估方法和客观的参照量,但受制于资源调查统计 精度的制约,空间上细化分析仍较难开展。而对服务价 值而言, 其评估的准确性, 取决于如何更加全面客观地 考虑价值评估因子和要素。但目前关键生态指标、物理 指标、产品价格缺乏权威性、统一性的调查、采集与公

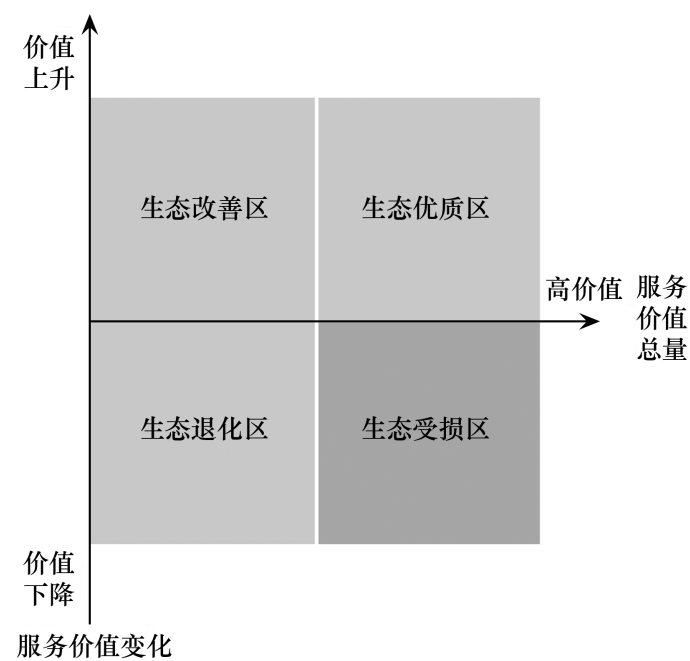

图 9 基于服务价值演变识别生态保护与修复重点

Fig.9 Identifying key areas of concern in the near future based on the evolution of service value 布, 给特定地区在地化调节系数的确定带来了较大困 难, 导致相同地区自然资源资产价值在不同研究中出现一定的浮动。从可比性出发,如何建立统一的评估标 准还有待进一步研究深化。

文化服务价值评估则难以全面客观进行量化,存在较大的限制因素和主观评价因素。如森林公园、公园 绿地等游咊型生态空间的文化服务价值，一般可通过条件价值法、享乐价格法、旅行费用法等方法,通过问卷 调查等方式,结合居民使用意愿进行评估。但目前相关研究以特定的某个公园评估为主,在区域尺度上应用 仍较为困难。为此, 本文以生态与乡村旅游总收人作为评估文化服务价值的基础, 并基于生态、乡村旅游兴趣 点的网络大数据, 通过空间递减分配的方法, 以期对文化服务价值进行在地化修正。但是, 由于现实中许多城 市公园、郊野公园免费运营, 对其文化服务价值有所低估, 难以客观反映其直接、间接服务价值, 也对后续基于 网格的空间分析应用有所影响。下一步研究可进一步结合热力图、手机信令等空间大数据,对不同类型公园 服务半径及服务人口进行评估分析，以进一步提升文化服务价值量化与空间化的准确性。

4.1.2 自然资源资产评估方法在不同层次国土空间生态修复规划中的适应性

国家建立“五级三类”的国土空间规划体系,为生态保护修复提供了丰富的空间规划工具。面向国土空 间规划，本文提出自然资源资产评估方法在国土空间规划生态修复方面的应用，可以有效支撑省域、市域，以 及部分范围较大区县的生态修复重点区域辨识和规划工作。但受资源调查统计口径、调查时点、统计精度制 约,尤其是统计部门的农林牧副渔经济统计数据大部分只能分解到区、县, 难以支撑区县级、镇街级尺度的 分析。

由此,自然资源资产评估方法在各级国土空间规划的推广应用,仍有待完善自然资源调查监测体系,以更 综合、更精准、更适时地反映自然资源综合特征, 提供基础数据支撑。同时,建议进一步完善自然资源资产评 估机制,在全国层面形成统一的“基础评价项+地区特色项”评估框架; 在省市层面, 建立常态化价值评估标准 发布机制, 公布当地当量因子年度价值,建立更具地域性与可比性的价值评估标准。

4.1.3 基于自然资源资产评估推动生态修复规划实施

本文探讨了通过自然资产评估开展生态修复规划编制的技术方法,但最为重要的是推动生态修复规划落 地实施。目前, 生态修复主要依靠政府主导和工程投资, 缺乏市场化运作以及更多主体的支撑。而自然资源 资产评估的价值量化，一方面可以支撑建立规划实施的评价、补偿、奖励机制，一方面有利于引人基于价格、交 
易、竞争等的市场化运作机制, 去实现自然资源与生态环境的保有保护、合理利用、修复提升。

实践中,已有通过自然资源资产价值开展生态修复及相关机制建设的探索。如德国的“生态价值分”制 度,通过生态修复机构开展栖息地生物多样性改善、退农还林等生态修复行为获得“生态价值分”,并将“价值 分”出售给需要进行土地开发的开发商获利的方式,吸引市场主体主动开展生态修复工作。又如我国浙江云 台通过将自然资源资产价值纳人土地出让金,并将获得的资金专门用于地区生态保护与修复工作的方式,拓 宽生态修复资金来源。

总之,自然资源资产评估有利于建立价值量化机制去推动更加广泛多元的生态保护与修复,但实践层面 还有待进一步探索和规范化、制度化。

\section{2 结论}

本文以直接市场法、当量因子法为基础整合了一套包含实物价值核算、服务价值评估的可对比、可量化自 然资产评估框架,并以广州为例提出了其在国土空间规划生态重要性地区识别、生态空间主导功能分区、生态 治理重点研判等应用,可为省级、市级,以及范围较大的区县级国土空间生态修复规划提供技术支撑。同时， 以广州为例提出了适合广州本地的当量因子在地化方式, 可为其他地区开展相关工作提供数据或方法上的 参考。

\section{参考文献 (References) :}

［1］颜文涛,萧敬豪,胡海,邹锦.城市空间结构的环境绩效:进展与思考.城市规划学刊,2012(5):50-59.

[2]陈新闯,李小倩,吕一河,刘红晓, 郭建英. 区域尺度生态修复空间辨识研究进展. 生态学报, 2019,39(23): 8717-8724.

[ 3 ] Daily G C. The value of nature and the nature of value. Science, 2000, 289(5478) : 395-396.

[ 4 ] Egoh B, Rouget M, Reyers B, Knigth AT, Cowling RM, Jaarsveld ASV, Welz A. Integrating ecosystem services into conservation assessment: A review. Ecological Economics, 2007, 63(4) : 714-721.

[ 5 ] Lautenbach S, Kugel C, Lausch A, Seppelt R. Analysis of historic changes in regional ecosystem service provisioning using land use data. Ecological Indicators, 2011, 11(2): 676-687.

[ 6 ] Wainger L A, King D M, Mack R N, Price EW, Maslin T. Can the concept of ecosystem services be practically applied to improve natural resource management decisions? Ecological Economics, 2010, 69(5): 978-987.

～ 7 ] 吴健生,黄乔,曹祺文.深圳市基本生态控制线划定对生态系统服务价值的影响.生态学报,2018,38(11):3756-3765.

[8] 黄心怡,赵小敏,郭熙,江叶枫,赖夏华.基于生态系统服务功能和生态敏感性的自然生态空间管制分区研究.生态学报, 2020,40(03)： 1065-1076.

[ 9 ］周可法,陈犧,张海波,李静,张清.干旱区生态资产遥感定量评估模型研究.干旱区地理,2004(4) :492-497.

[10]朱文泉,高清竹,段敏捷, 郭亚齐,李玉娥,万运帆,边多,韦兰亭.藏西北高寒草原生态资产价值评估. 自然资源学报, 2011,26(3):419-428.

[11] 潘耀忠, 史培军, 朱文泉, 顾晓鹤, 范一大, 李京.中国陆地生态系统生态资产遥感定量测量.中国科学 (D 辑: 地球科学), 2004(4) : 375-384.

［12］于德永,潘耀忠,龙中华,王艳艳,刘釒基于遥感技术的云南省生态系统水土保持价值测量.水土保持学报,2006(2):174-178.

[13] 胡聑, 张艳萍, 文秋霞, 陈超, 刘天星, 王震, 许开鹏. 北京城市生态系统总体资产动态及其与城市发展关系.生态学报, 2006(7):2207-2218.

[14] 黄兴文,陈百明.中国生态资产区划的理论与应用.生态学报,1999(5):14-18.

［15］ 黄桂林等. 青海省生态资产评估. 北京: 中国林业出版社,2016:1-26.

[16] Costanza R, D'Arge R, Groot RD, Farber S, Grasso M, Hannon B, Limburg K, Naeem S, O' Neill RV. The value of the world's ecosystem services and natural capital. Nature, 1997, 387: 253-260.

[17] 谢高地, 鲁春霞, 成升魁. 全球生态系统服务价值评估研究进展.资源科学,2001(6):5-9.

[18］谢高地,张钇锂,鲁春霞,郑度,成升鬼.中国自然草地生态系统服务价值.自然资源学报, 2001(1): 47-53.

[19] 杨琼,陈章和,沈鸿标.白云山森林生态系统间接经济价值评估.生态科学,2002(1):72-75.

[20］谢高地, 鲁春霞, 冷允法, 郑度, 李双成. 青藏高原生态资源的价值评估. 自然资源学报, 2003, 18(2): 189-196

[21］谢高地, 肖玉, 甄霖, 鲁春霞. 我国粮食生产的生态服务价值研究. 中国生态农业学报, 2005(3):10-13.

[22] 谢高地, 甄霖, 鲁春霞, 肖玉, 陈操. 一个基于专家知识的生态系统服务价值化方法. 自然资源学报, 2008, 23(5): 911-919

［23］于谦龙.乌鲁木齐城市森林生态系统生态资产定量研究.安徽农业科学, 2007, (22):6710-6712.

［24］郝慧梅,郝永利,田党生.基于 RS 与 GIS 的 LUCC 生态服务功能价值动态核算.国土资源遥感,2011(4):115-120。

[25] 谢高地,张彩霞,张昌顺,肖玉,鲁春霞.中国生态系统服务的价值.资源科学, 2015,37(9):1740-1746.

[26] 吴婕,李晓轫,龙闹,萧敬豪.城市密集地区生态廊道网络规划研究——以州都会区为例. 现代城市研究, 2017(1):61- 67.

[27] 吴志峰,黄银华,姜春.广州市土壤与植被碳蓄积及其空间格局分析.广州大学学报 (自然科学版),2014,13(3): 73-79+2.

[28］谢高地,张彩霞,张雷明,陈文辉,李士美. 基于单位面积价值当量因子的生态系统服务价值化方法改进. 自然资源学报, 2015,30(8)： 1243-1254.

[29] 吴艳艳. 城市化过程广州土地覆盖变化对净初级生产力格局的影响 [D ].广州: 中山大学,2016

[30］朱文泉,潘耀忠,龙中华,陈云浩,李京, 扈海波.基于 GIS 和 RS 的区域陆地植被 NPP 估算一一中国内蒙古为例.遥感学报, 2005(3)： 300-307.

[31] 萧敬豪, 陈惠斐. 试谈规划环境目标制定的程序性及实体性问题//中国城市规划学会、贵阳市人民政府.新常态: 传承与变革一一 2015 中 国城市规划年会论文集 (07 城市生态规划).北京市: 中国城市规划学会, 2015:10.

[32] 萧敬豪. 城乡规划过程的环境绩效分析及优化途径 [D]. 重庆:重庆大学,2014. 